\begin{tabular}{l}
\hline MATAPPA: Jurnal Pengabdian Kepada Masyarakat \\
Volume $2 \mid$ Nomor $1 \mid$ Maret |2019 \\
e-ISSN: $2614-6673$ dan p-ISSN: $2615-5273$ \\
\begin{tabular}{|l|l|} 
(c) (1) This work is licensed under a Creative Commons Attribution \\
\hline
\end{tabular} \\
\hline
\end{tabular}

\title{
Pelatihan Peningkatan Nilai Produk Kerajinan Tangan Decoupage dan Pemasaran Produk untuk Ibu Rumah Tangga
}

\section{Nurmaya $^{1}$, Nova Eka Diana ${ }^{2}$, Indah Kurnianingsih ${ }^{3}$, Rosini $^{4}$}

\begin{tabular}{l}
\hline Keywords : \\
Decoupage; \\
E-Commerce; \\
Numbered Heads Together \\
\\
Corespondensi Author \\
Prodi Teknik Informatika, \\
Fakultas Teknologi Informasi, \\
Universitas YARSI \\
Jl. Letjend Suprapto, Cempaka \\
Putih, Jakarta Pusat \\
Email: nurmaya@ @arsi.ac.id \\
History Artikel \\
Received: 07-02-2019; \\
Reviewed: $15-02-2019 ;$ \\
Revised: $01-03-2019 ;$ \\
Accepted: $24-03-2019 ;$ \\
Published: $28-03-2019$
\end{tabular}

\begin{abstract}
Abstrak. Pelatihan ini bertujuan untuk meningkatkan kemandirian ekonomi Ibu Rumah Tangga di RW 011 Tebet Timur Jakarta Selatan dan Pemberdayaan Perempuan RT 05 Rorotan Jakarta Utara. Pelaksanaan kegiatan menggunakan metode Numbered Heads Together (NHT) yang terdiri dari 4 tahapan yaitu pembentukan kelompok, pemberian tugas, pembangunan ide dan kreasi yang dipandu oleh fasilitator, dan penilaian produk berdasarkan respon pasar. Hasil pelatihan menunjukkan adanya peningkatan nilai produk yang dibuat oleh Ibu Rumah Tangga selaku mitra. Kerajinan decoupage berhasil terjual sebanyak 20 dari 43 barang melalui Bazar dan Media Sosial dengan keuntungan rata - rata sebesar $25 \%$ dari harga modal. Akan tetapi, tidak ada barang yang terjual melalui E-Commerce disebabkan toko online mitra belum dikenal oleh masyarakat. Secara keseluruhan pelaksanaan kegiatan dapat memberikan peluang usaha baru bagi Ibu Rumah Tangga. Untuk meningkatkan hasil penjualan terutama melalui media E-Commerce, diperlukan pelatihan strategi pemasaran di masa mendatang.
\end{abstract}

\begin{abstract}
The purpose of this training is to increase the independent income of homemakers in RW 011 Tebet Timur Jakarta Selatan and RT 05 Rorotan Jakarta Utara. The training program used Number Heads Together (NHT) consists of four stages such as forming the groups, giving assignments, constructing the ideas and creativities assisted by the instructor, and evaluating the products based on the market's responses. The training results showed the value of the products, created by the homemakers, increases. There were 20 of 43 decoupages were sold successfully in Bazaar and Social Media with the profit average is $25 \%$ of the capital cost. However, none of the items were sold through E-Commerce since society did not yet recognize the trainees' online shops. Overall, the training could give the new business opportunity for the homemakers. To increase sales, especially through E-Commerce, the training of marketing strategy is needed for the future.
\end{abstract}




\section{PENDAHULUAN}

Pelatihan peningkatan nilai produk kerajinan tangan beserta pemasarannya untuk Ibu Rumah Tangga dilaksanakan dalam rakaian kegiatan Ipteks bagi Masyarakat (IbM). Metode decoupage, yaitu kerajinan memotong dan menempel ke sebuah obyek dengan pernis dan pelitur (thespurce, 2017), dimanfaatkan untuk meningkatkan nilai produk. Sedangkan media sosial, e-commerce dan bazar digunakan untuk pemasaran produk.

Tujuan dari pelatihan ini adalah untuk menyelesaikan berbagai permasalah yang terdapat pada Ibu PKK RW 011 Kelurahan Tebet Timur selaku Mitra 1 dan Pemberdayaan Perempuan RT 05 selaku Mitra 2. Kurangnya kegiatan yang berorientasi pada kemandirian ekonomi, dan kurangnya pemanfaatan teknologi dalam menunjang perekonomian adalah masalah yang terjadi di Mitra 1. Sedangkan Mitra 2 memiliki keterampilan hardkill dan softkill yang rendah, memiliki perekonomian dan jenjang pendidikan yang rendah serta penguasaan teknologi informasi yang masih kurang. Untuk meningkatkan kemandirian ekonomi pada kedua mitra, maka pelatihan peningkatan nilai produk kerajinan decoupage diberikan kepada kedua mitra.

Media sosial seperti WhatsApp telah banyak digunakan sebagai media dalam memasarkan produk. Layanan gratis dapat diakses kapan saja dan dimana saja, terciptanya komunikasi yang lancar antara pembeli dan penjual adalah keunggulan penggunaan media sosial dalam kegiatan usaha (Sholihin, Arianto, \& Khasanah, 2018).

E-Commerce, transaksi jual beli secara elektronik melalui jaringan internet, memberikan kemudahan bagi para pengusaha dalam memperluas pangsa pasar. Beberapa keunggulan yang dimiliki E-Commerce diantaranya mudah dalam mempromosikan produk, tidak ada batasan interaksi antara penjual dan pembeli, namun tidak membutuhkan biaya yang tinggi untuk mendukung interaksi antara penjual dan pembeli (Prihadi \& Susilawati, 2018).

Keunggulan yang dimiliki oleh Media Sosial dan E-Commerce menjadikan media tersebut sebagai platform yang tepat untuk mengevaluasi produk-produk yang dihasilkan oleh kedua mitra secara langsung ke Masyarakat. Tidak hanya melalui Media Sosial dan E-Commerce, pemasaran produk juga dilakukan di bazar.

Pelatihan dasar teknik decoupage dan $e$ commerce sebelumnya telah diberikan kepada mitra 1 yang berlokasi di Jl. Tebet Timur Dalam IV Jakarta Selatan, dan mitra 2 yang beralamat di Perum Green Garden RT 05 Kelurahan Rorotan Kecamatan Cilincing Jakarta Utara (Nurmaya, Kurnianingsih, Rosini, \& Diana, 2017). Peningkatan keterampilan dalam pembuatan kerajinan decoupage pada pelatihan sebelumnya ditunjukkan dengan keberhasilan menghasilkan 125 kerajinan. Peningkatan pengetahuan e-commerce juga terjadi dengan rata-rata $79 \%$ memahami definisi, fungsi dan penggunaan e-commerce dalam memasarkan barang.

Untuk meningkatkan level kemampuan kedua mitra agar dapat menjadi pengrajin profesional dalam membuat kerajinan decoupage yang siap untuk dipasarkan ke masyarakat, pelatihan peningkatan nilai produk kerajinan decoupage dan pemasaran produk melalui beberapa media diantaranya $e$ commerce, media sosial, dan bazar diberikan kembali kepada kedua mitra. Penilaian terhadap peningkatan kemampuan para mitra juga dilakukan berdasarkan respon pasar terhadap barang kerajinan yang dihasilkan.

\section{METODE}

Pelatihan ini mengadaptasi metode Numbered Heads Together (NHT) dalam proses pengajarannya. NHT adalah sebuah metode pembelajaran yang berorientasi pada kerja sama antar anggota kelompok dalam mencapai tujuan bersama dan memiliki 8 langkah (Huda, 2011; Suwarni, 2018). Peningkatan kemampuan berfikir serta interaksi sosial individu adalah manfaat dari NHT (Lease \& Corebima, 2017). Gambar 1 menggambarkan tahapan pelatihan yang terdiri dari 4 langkah yang diadaptasi dari 8 langkah NHT.

Tahapan pertama, para peserta mitra 1 dan mitra 2 dibentuk menjadi kelompok kecil yang terdiri dari 3 sampai dengan 4 orang. Masing-masing mitra membentuk 5 kelompok. Kemudian, di tahapan kedua setiap kelompok diberikan tugas untuk membuat kerajinan decoupage. Media dasar yang digunakan untuk kerajinan decoupage berjumlah 43 barang dengan berbagai macam tipe antara lain tas berjenis clutch, pouch, hand bag yang memiliki ukuran kecil sampai dengan besar, dan tempat tisu. Semua media berbahan pandan polos. Pada 
tahapan ketiga, instruktur pelatihan menjadi fasilitator dalam membangun ide dan kreasi setiap kelompok dalam membuat kerajinan decoupage. Evaluasi terhadap peningkatan kemampuan para peserta dinilai berdasarkan respon pasar. Hasil kerajinan dipasarkan ke masyarakat melalui bazar, media sosial dan $E$ Commerce. Kegiatan ini dilakukan di tahapan keempat. Rincian pelaksanaan kegiatan dapat dilihat pada Tabel 1.

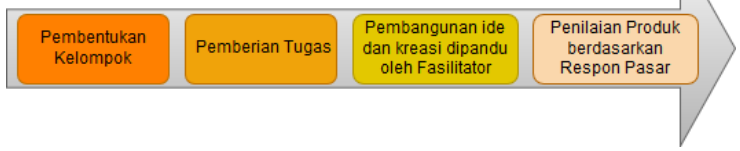

Gambar 1. Tahapan Pelaksanaan Pelatihan

Tabel 1. Rincian Pelaksanaan Kegiatan

\begin{tabular}{|c|c|c|c|c|}
\hline No & Kegiatan & Unit & Pelaksana & $\begin{array}{c}\text { Lokasi } \\
\text { Kegiatan }\end{array}$ \\
\hline 1 & $\begin{array}{l}\text { Pembentukan } \\
\text { Kelompok }\end{array}$ & $\begin{array}{l}\text { Mitra } 1: 5 \text { Kelompok (18 orang) } \\
\text { Mitra } 2: 5 \text { Kelompok (15 orang) }\end{array}$ & Tim Pelaksana & Mitra \\
\hline 2 & $\begin{array}{l}\text { Pemberian } \\
\text { Tugas membuat } \\
\text { Kerajinan } \\
\text { Decoupage } \\
\end{array}$ & \multirow{2}{*}{$\begin{array}{l}\text { Mitra } 1: 21 \text { Media (Tas \& Clutch } \\
\text { polos bahan pandan) \& } 5 \text { decoupage } \\
\text { starter kits } \\
\text { Mitra } 2: 22 \text { Media (Tas, Clutch, dua } \\
\text { kotak tisu polos bahan pandan) \& } 5 \\
\text { decoupage starter kits }\end{array}$} & Tim Pelaksana & Mitra \\
\hline 3 & $\begin{array}{lr}\text { Pembangunan } \\
\text { Ide dan } & \text { Kreasi } \\
\text { dipandu } & \text { oleh } \\
\text { Fasilitator } & \\
\end{array}$ & & $\begin{array}{l}\text { Tim Pelaksana } \\
\text { dan Mitra }\end{array}$ & Mitra \\
\hline 4 & $\begin{array}{l}\text { Penilaian } \\
\text { Produk } \\
\text { berdasarkan } \\
\text { Respon Pasar }\end{array}$ & $\begin{array}{l}\text { Penjualan } 43 \text { Kerajian Decoupage } \\
\text { melalui Bazar, Media Sosial, E- } \\
\text { Commerce }\end{array}$ & $\begin{array}{l}\text { Tim Pelaksana } \\
\text { dan Mitra }\end{array}$ & Mitra \\
\hline
\end{tabular}

\section{HASIL DAN PEMBAHASAN}

Pelaksanaan kegiatan pelatihan dilakukan selama 7 hari kepada kedua Mitra (Gambar 2). Masing-masing mitra membentuk 5 kelompok.

Total kerajinan decoupage yang berhasil dibuat kedua mitra sebesar 43 barang. Mitra 1 memproduksi sebanyak 21 tas decoupage. Dua puluh dua kerajinan decoupage yang terdiri dari 20 tas dan 2 tempat tisu dihasilkan oleh Mitra 2 (Gambar 3).

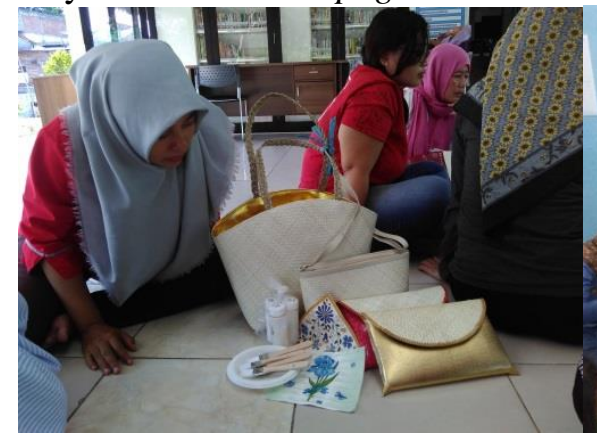

(a)

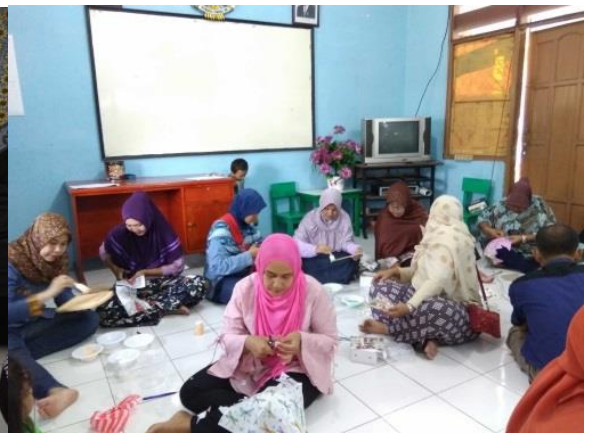

(b)

Gambar 2. Pelaksanaan kegiatan di Mitra 1 (a) dan kegiatan di Mitra 2 (b) 


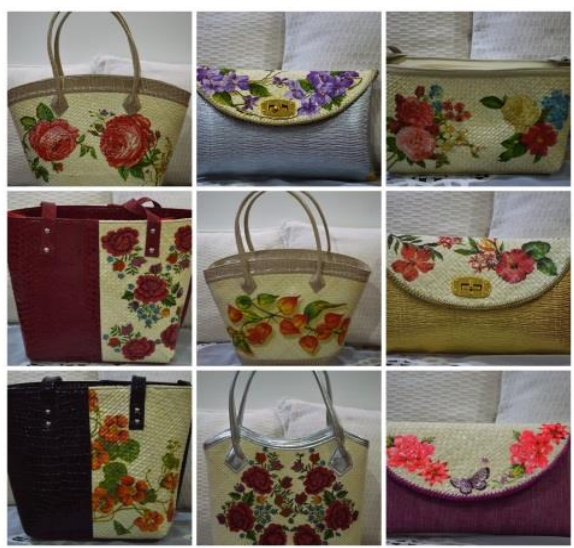

(a)
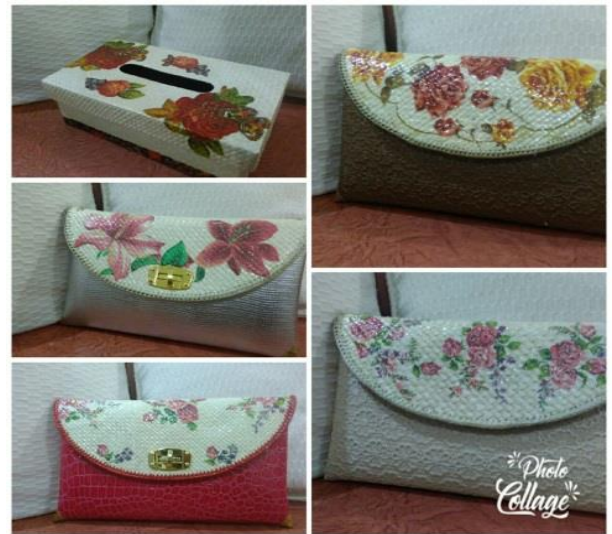

(b)

Gambar 3. Kerajinan Decoupage Mitra 1 (a) dan Kerajinan Decoupage Mitra 2 (b)

Hasil kerajinan kemudian dipasarkan melalui 3 media yaitu e-commerce, media sosial dan bazar. E-commerce yang digunakan adalah Bukalapak, media sosial adalah WhatsApp, dan bazar diselenggarakan di Rumah Sakit Islam Jakarta Cempaka Putih selama dua hari (Gambar 4).

Tabel 2 menunjukkan modal yang dihabiskan untuk setiap barang kerajinan yang telah dibuat oleh kedua mitra berdasarkan model media dasar yang digunakan diantaranya clutch, pouch, tas dengan berbagai model, dan kotak tisu. Rencana harga jual dan realisasi harga jual serta media pemasaran yang digunakan juga dipaparkan di tabel 2. Hasil penjualan menunjukkan bahwa masing-masing kerajinan decoupage memberikan keuntungan rata-rata 25\% dari harga modal. Total barang terjual sebanyak 20 kerajinan.

Sebanyak $75 \%$ kerajinan yang terjual adalah produk Mitra 1, sedangkan 25\% merupakan kerajinan yang dihasilkan oleh Mitra 2. Hal ini memperlihatkan bahwa hasil kerajinan mitra 1 lebih banyak diminati dibandingkan hasil kerajinan mitra 2. Kreasi yang menarik dan indah menjadi keunggulan dari produk yang dihasilkan oleh mitra 1. Berdasarkan hasil penilaian instruktur selama pelatihan, mitra 1 memiliki rasa seni dan keterampilan yang lebih tinggi dibandingkan dengan mitra 2 , dan juga menghasilkan produk yang lebih rapih. Persentase total penjualan kerajinan decoupage untuk kedua mitra dapat dilihat pada Gambar 5.

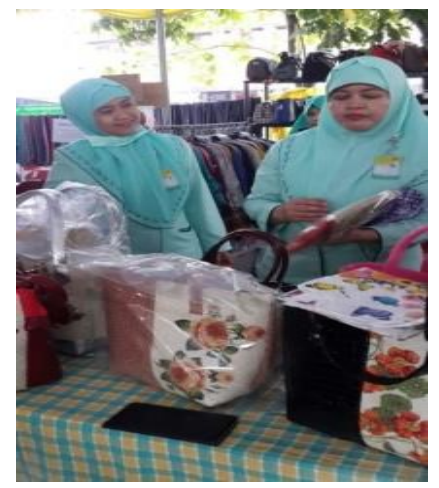

Gambar 4. Pemasaran Kerajinan Decoupage di Bazar Rumah Sakit Islam

Tabel 2. Detail Hasil Kerajinan Decoupage

\begin{tabular}{lllllc}
\hline Item & $\begin{array}{l}\text { Modal } \\
\text { (Rp.) }\end{array}$ & $\begin{array}{l}\text { Harga Jual } \\
\text { (Rencana) }\end{array}$ & $\begin{array}{l}\text { Harga Jual } \\
\text { (Realisasi) }\end{array}$ & Media & $\begin{array}{c}\text { Total } \\
\text { Terjual }\end{array}$ \\
\hline Clutch & 55000 & 85000 & $\begin{array}{l}75000 \text { s.d } \\
85000\end{array}$ & $\begin{array}{l}\text { Bazar dan } \\
\text { Media } \\
\text { Sosial }\end{array}$ & 6 \\
& & & & Media & 1 \\
Tas Model Apel & 87500 & 135000 & 135000 & $\begin{array}{l}\text { Sosial } \\
\text { Sila }\end{array}$
\end{tabular}




\begin{tabular}{|c|c|c|c|c|c|}
\hline Tas Model Bendera & 87500 & 135000 & $\begin{array}{l}90000, \\
115000\end{array}$ & Bazar & 2 \\
\hline Pouch & 70000 & 110000 & $\begin{array}{l}80000 \\
100000\end{array}$ & $\begin{array}{l}\text { Bazar dan } \\
\text { Media } \\
\text { Sosial }\end{array}$ & 2 \\
\hline $\begin{array}{l}\text { Tas Model WB } \\
\text { Ukuran Sedang dan } \\
\text { Kecil }\end{array}$ & 90000 & 135000 & 135000 & $\begin{array}{l}\text { Media } \\
\text { Sosial }\end{array}$ & 3 \\
\hline $\begin{array}{l}\text { Tas Model } \\
\text { Gelombang }\end{array}$ & 85000 & 130000 & 100000 & Bazar & 2 \\
\hline Tas Model Serut & 65000 & 120000 & - & - & - \\
\hline $\begin{array}{l}\text { Tas Model Bakul } \\
\text { Krem }\end{array}$ & 70000 & $\begin{array}{l}132500 \text { s.d } \\
135000\end{array}$ & $\begin{array}{l}80000 \\
150000\end{array}$ & $\begin{array}{l}\text { Bazar dan } \\
\text { Media } \\
\text { Sosial }\end{array}$ & 2 \\
\hline Tas Model Piramid & 85000 & 150000 & 100000 & $\begin{array}{l}\text { Media } \\
\text { Sosial }\end{array}$ & 1 \\
\hline Kotak Tisu & 50000 & 70000 & 70000 & Bazar & 1 \\
\hline
\end{tabular}

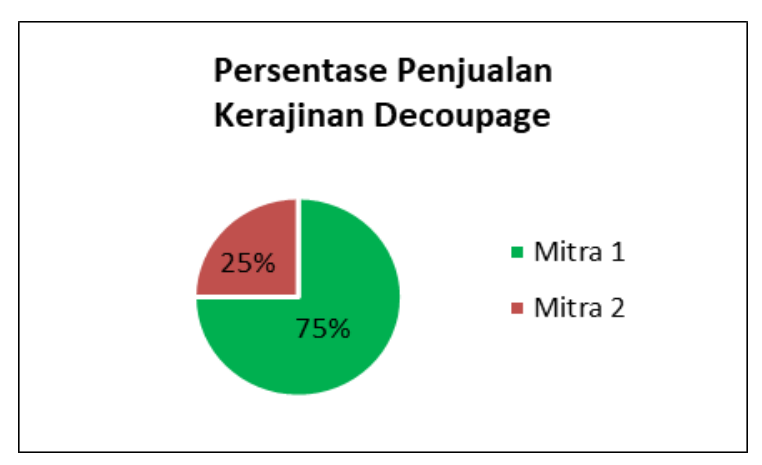

Gambar 5. Persentase Penjualan Kerajinan Decoupage Mitra 1 dan Mitra 2

Gambar 6 menunjukkan persentase penjualan barang dengan menggunakan tiga media pemasaran. Lima puluh persen dari 20 kerajinan decoupage terjual melalui Bazar. Hasil yang sama ditunjukkan oleh Media Sosial yang berhasil menjual 50\% dari 20 kerajinan decoupage yang terjual. Namun kesuksesan penjualan tidak ditunjukkan oleh media pemasaran E-Commerce. Hasil penjualan memperlihatkan bahwa tidak ada kerajinan yang terjual melalui media tersebut. Hal ini dikarenakan, toko online mitra 1 dan mitra 2 yang telah dibuat di pelatihan sebelumnya

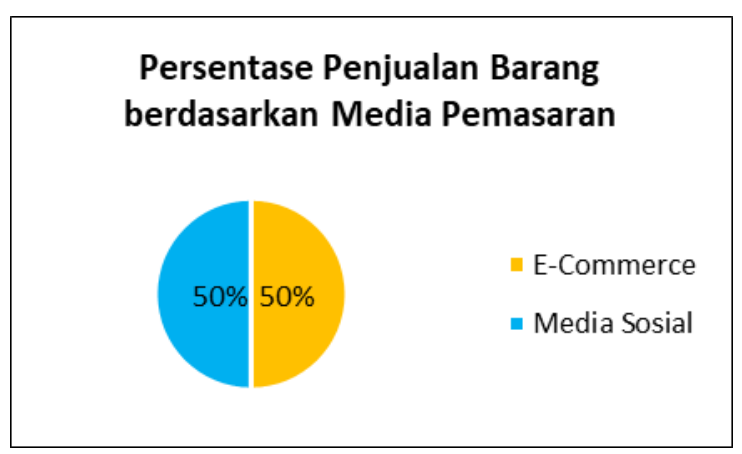

Gambar 6. Persentase Penjualan Barang berdasarkan Media Pemasaran

(Nurmaya et al., 2017) belum dikenal oleh masyarakat luas. Media Sosial dapat menjual barang dengan mudah dikarenakan penyebaran informasi yang sangat cepat. Barang dapat dilihat dan disentuh adalah keunggulan penjualan melalui Bazar.

Hasil penjualan juga menunjukkan bahwa kerajinan decoupage dari media Clutch paling banyak diminati oleh pasar, dimana 30\% dari total kerajinan yang terjual adalah Clutch. Clutch yang terjual melalui bazar dan media sosial memiliki harga Rp 75.000 sampai dengan Rp 85.000. 


\section{MATAPPA: Jurnal Pengabdian Kepada Masyarakat.}

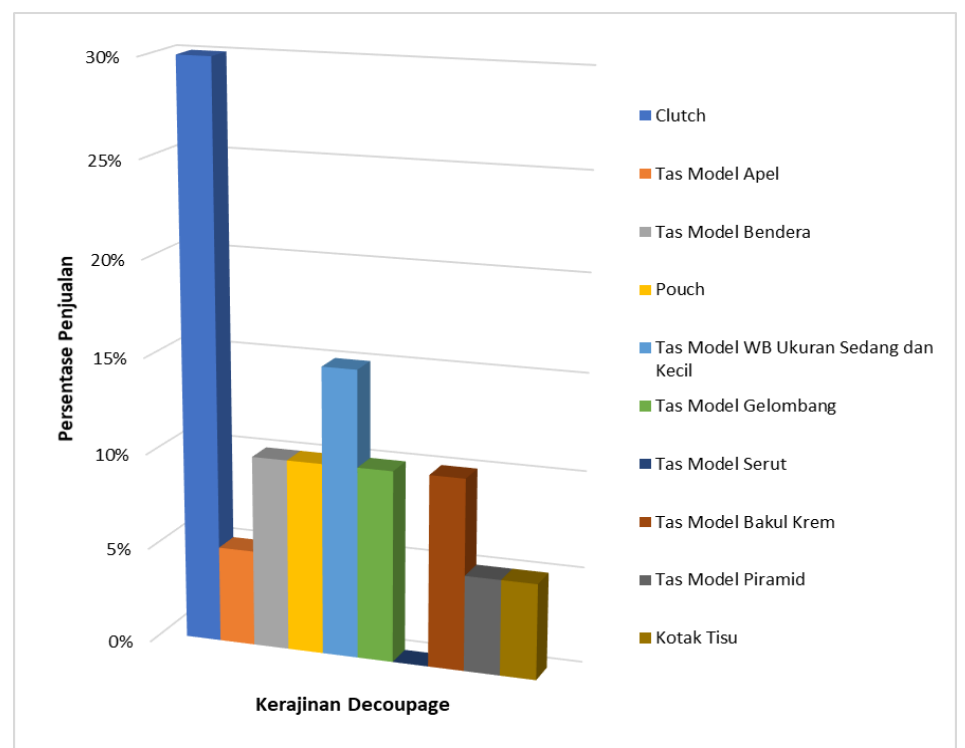

Gambar 7. Persentase Penjualan Kerajinan Decoupage berdasarkan Model

Tas model $\mathrm{Wb}$ ukuran sedang dan kecil juga diminati oleh masyarakat dengan penjualan $15 \%$ seharga $\mathrm{Rp} \quad 135.000$, sehingga menempatkan kerajinan decoupage model ini berada di posisi kedua terbanyak dibeli oleh masyarakat. Posisi ketiga ditempati oleh model Pouch, Tas model Bendera dan Gelombang dengan total penjualan masing-masing $10 \%$. Harga pouch berhasil terjual dengan harga $\mathrm{Rp}$ 80.000 dan Rp 100.000, sedangkan tas bendera terjual masing-masing Rp 100.000. Tas model serut menjadi kerajinan yang tidak diminati oleh masyarakat. Tidak ada satupun kerajinan dengan model tersebut yang terjual. Model dasar yang sederhana, ukuran yang besar dan tidak dapat digunakan di segala kegiatan menjadi alasan masyarakat tidak membeli produk tersebut. Persentase penjualan setiap model kerajinan decoupage diperlihatkan pada Gambar 7.

\section{SIMPULAN DAN SARAN}

Pelatihan peningkatan nilai kerajinan dengan metode decoupage dan pemasaran produk diberikan kepada dua mitra yaitu Ibu PKK RW 011 Kel Tebet Timur Jakarta Selatan selaku Mitra 1 dan Pemberdayaan Perempuan RT. 05 Kel Rorotan Jakarta Utara selaku Mitra 2. Pelatihan diberikan dengan metode Numbered Heads Together dimana peserta dibentuk menjadi kelompok dan instruktur sebagai fasilitator dalam mengarahkan dan memberikan masukan kepada kelompok selama pembuatan kerajinan decoupage. Sebanyak 43 kerajinan decoupage berhasil dibuat oleh kedua mitra selama pelatihan berlangsung.
Produk yang dihasilkan kemudian dievaluasi ke masyarakat dengan memasarkan secara langsung menggunakan ketiga media yaitu bazar, media sosial dan e-commerce. Hasil penjualan menunjukkan bahwa produk kerajinan kedua mitra telah dapat diterima oleh masyarakat, $46 \%$ dari total kerajinan yang telah diproduksi berhasil terjual. Produk Mitra 1 lebih digemari oleh masyarakat. Dari produk yang terjual, $75 \%$ berasal dari Mitra 1 dan 25\% dari Mitra 2. Hasil kreasi seni yang indah serta kerapihan produk merupakan keunggulan dari produk Mitra 1.

Bazar dan media sosial menjadi media pemasaran paling efektif dalam penjualan produk karena telah berhasil menjual masingmasing 50\% dari total penjualan barang. ECommerce menjadi media pemasaran yang belum berhasil menjual produk karena belum dikenal oleh masyarakat.

Penjualan kerajinan decoupage dapat memberikan keuntungan kepada mitra rata-rata sebesar $25 \%$ dari harga modal untuk setiap produk. Kerajinan decoupage dengan media dasar Clutch adalah produk yang banyak digemari oleh masyarakat dengan total penjualan sebanyak 30\% dengan harga jual Rp 75.000 s.d Rp 85.000.

Keseluruhan hasil pelaksanaan pelatihan menunjukkan hasil yang positif dan peluang usaha untuk para mitra bagi para perempuan khususnya ibu rumah tangga. Untuk meningkatkan usaha yang telah dibangun, pelatihan strategi pemasaran produk perlu dilakukan di masa mendatang. 


\section{DAFTAR RUJUKAN}

Huda, M. (2011). Cooperative Learning metode, teknik, struktur dan model penerapan. Yogyakarta: Pustaka Pelajar.

Lease, M., \& Corebima, A. D. (2017). The effect of numbered heads together (NHT) cooperative learning models on the cognitive achievement of students with different academic ability. Journal of Physics: Conference Series 795 012071, $795 . \quad$ https://doi.org/10.1088/17426596/795/1/012071

Nurmaya, Kurnianingsih, I., Rosini, \& Diana, N. E. (2017). IBM PELATIHAN DECOUPAGE DAN E-COMMERCE UNTUK MENINGKATKAN EKONOMI IBU RUMAH TANGGA. In Prosiding Seminar Hasil Pengabdian Kepada Masyarakat (SNP2M) 2017 (pp. 160-165). Retrieved from http://snp2m2017.poliupg.ac.id/prosidingsnp2m2017/

Prihadi, D., \& Susilawati, A. D. (2018). Pengaruh kemampuan e-commerce dan promosi di media sosial terhadap kinerja pemasaraan. BENEFIT: Jurnal Manajemen Dan Bisnis, 3(1), 15-20.
Sholihin, M. R., Arianto, W., \& Khasanah, D. F. (2018). Keunggulan Sosial Media Dalam Perkembangan Ekonomi Kreatif Era Digital Di Indonesia. In Prosiding Ekonomi Kreatif Di Era Digital (pp. 149160). Retrieved from http://jurnal.unmuhjember.ac.id/index.php/ PEKED/article/view/1286/1044

Suwarni, S. (2018). OPTIMALISASI PEMBELAJARAN NUMBERED HEADS TOGETHER (NHT) UNTUK MENINGKATKAN MINAT BELAJAR DAN HASIL BELAJAR PRAKARYA DAN KEWIRAUSAHAAN BAGI SISWA KELAS XI TKJ-A DI SMK N 2 SURAKARTA TAHUN PELAJARAN 2017/2018. Jurnal Pendidikan Dwija Utama: Edisi Agustus 2018, 9(40), 91.

Thespruce, 2017, How to Decoupage: Learn how to decoupage and explore free projects and recipes, Retrieve from https://www.thespruce.com/how-todecoupage-1244290 